\title{
Difference in postprandial GLP-1 response despite similar glucose kinetics after consumption of wheat breads with different particle size in healthy men
}

\author{
Coby Eelderink ${ }^{1,2} \cdot$ Martijn W. J. Noort $^{3} \cdot$ Nesli Sozer $^{4} \cdot$ Martijn Koehorst $^{5}$. \\ Jens J. Holst ${ }^{6}$ • Carolyn F. Deacon ${ }^{6} \cdot$ Jens F. Rehfeld $^{7} \cdot$ Kaisa Poutanen $^{4}$. \\ Roel J. Vonk ${ }^{1} \cdot$ Lizette Oudhuis $^{2,3} \cdot$ Marion G. Priebe ${ }^{1,2}$
}

Received: 31 May 2015 / Accepted: 10 January 2016 / Published online: 8 February 2016

(C) The Author(s) 2016. This article is published with open access at Springerlink.com

\begin{abstract}
Purpose Underlying mechanisms of the beneficial health effects of low glycemic index starchy foods are not fully elucidated yet. We varied the wheat particle size to obtain fiber-rich breads with a high and low glycemic response and investigated the differences in postprandial glucose kinetics and metabolic response after their consumption.

Methods Ten healthy male volunteers participated in a randomized, crossover study, consuming ${ }^{13} \mathrm{C}$-enriched breads with different structures; a control bread (CB) made from wheat flour combined with wheat bran, and a kernel bread $(\mathrm{KB})$ where $85 \%$ of flour was substituted with
\end{abstract}

Electronic supplementary material The online version of this article (doi:10.1007/s00394-016-1156-6) contains supplementary material, which is available to authorized users.

Coby Eelderink

c.eelderink@umcg.nl

1 Center for Medical Biomics, University Medical Center Groningen, University of Groningen, Hanzeplein 1, 9713 GZ Groningen, The Netherlands

2 Top Institute Food and Nutrition, Wageningen, The Netherlands

3 TNO Food and Nutrition, Zeist, The Netherlands

4 VTT Technical Research Centre of Finland, Espoo, Finland

5 Department of Laboratory Medicine, Center for Liver Digestive and Metabolic Diseases, University Medical Center Groningen, University of Groningen, Groningen, The Netherlands

6 NNF Center for Basic Metabolic Research, Department of Biomedical Sciences, The Panum Institute, University of Copenhagen, Copenhagen, Denmark

7 Department of Clinical Biochemistry, Rigshospitalet, University of Copenhagen, Copenhagen, Denmark broken wheat kernels. The structure of the breads was characterized extensively. The use of stable isotopes enabled calculation of glucose kinetics: rate of appearance of exogenous glucose, endogenous glucose production, and glucose clearance rate. Additionally, postprandial plasma concentrations of glucose, insulin, glucagon, incretins, cholecystokinin, and bile acids were analyzed.

Results Despite the attempt to obtain a bread with a low glycemic response by replacing flour by broken kernels, the glycemic response and glucose kinetics were quite similar after consumption of $\mathrm{CB}$ and $\mathrm{KB}$. Interestingly, the glucagon-like peptide-1 (GLP-1) response was much lower after KB compared to CB (iAUC, $P<0.005$ ). A clear postprandial increase in plasma conjugated bile acids was observed after both meals.

Conclusions Substitution of $85 \%$ wheat flour by broken kernels in bread did not result in a difference in glucose response and kinetics, but in a pronounced difference in GLP-1 response. Thus, changing the processing conditions of wheat for baking bread can influence the metabolic response beyond glycemia and may therefore influence health.

Keywords Glucagon-like peptide-1 - Glycemic index · Glucose kinetics · Bile acids · Wheat kernels · Bread processing

\section{Introduction}

Consumption of foods with a low glycemic index (GI) instead of those with a high GI is considered beneficial for health, being associated with a decreased risk for the development of obesity, insulin resistance, and type 2 diabetes (T2DM) [1-5], although this association is not always 
found [6]. Based on results from a prospective cohort study, it was suggested that replacement of high GI bread by low GI bread in the diet may reduce the risk of developing T2DM [7]. Possible explanations were, for instance, that consumption of a low GI diet might be associated with less weight gain [4] or decreased development of $\beta$-cell failure and insulin resistance $[1,3]$. However, the underlying mechanisms responsible for the beneficial effects need further study.

The postprandial glycemic response obviously depends on intestinal glucose influx, but is also influenced by suppression of endogenous glucose production (EGP) and increased glucose uptake in tissues, processes that are mainly regulated by the pancreatic hormones insulin and glucagon. The incretin hormones glucose-dependent insulinotropic polypeptide (GIP) and glucagon-like peptide-1 (GLP-1), released postprandial from intestinal $\mathrm{K}$ and $\mathrm{L}$ cells, respectively, are known to potentiate the insulin response to a carbohydrate-rich meal and are therefore important factors in glucose metabolism. Besides their role as incretin hormones, GIP is involved in fat metabolism [8], and GLP-1 is involved in decreasing gastric emptying rate [9], suppression of glucagon [10], as well as increasing satiety [11], and, in rodents, preserving $\beta$-cell function [12]. Nowadays, bile acids (BAs) are also being recognized as signaling molecules in glucose metabolism. For instance, overexpression of the BA receptor TGR5 [13] and administration of taurocholic acid (TCA) [14] in mice was associated with elevated GLP-1 concentrations in response to an oral glucose tolerance test (OGTT). Although BAs are mainly released in response to fat ingestion, an increase in several plasma conjugated BAs was found after an OGTT $[15,16]$. Thus, BAs, as well as (indirectly) the gastrointestinal hormone cholecystokinin (CCK) which stimulates gall bladder contraction, might also play a role in glucose metabolism after consumption of a carbohydrate-rich meal.

We were, therefore, interested in studying both the postprandial glucose kinetics and the metabolic responses to bread with a high and a low glycemic response, using wheat particle size as a variable factor. Postprandial glucose responses to wheat products prepared with different flour or grain particle size have been shown to decrease with increasing particle size [17], likely explained by decreasing the rate of amylolysis. Replacement of finely ground wheat flour by increasing the proportion of cracked wheat in bread (to 50 and $75 \%$ ) also resulted in a reduction in GI [18].

In this crossover study, we investigated the metabolic effects of consumption of two ${ }^{13} \mathrm{C}$-labeled wheat breads, with the same overall composition, only varying in structure; a bread prepared with flour and $85 \%$ broken wheat kernels and a control bread made from wheat flour combined with wheat bran, to obtain a similar dietary fiber content in both breads. We hypothesized that, due to the variation in particle size, the glycemic response, the underlying glucose kinetics, and possibly other factors involved in glucose metabolism would be different between both breads.

\section{Subjects and methods}

\section{Subjects}

Ten healthy men [age $24 \pm 0.6$ years, BMI $22 \pm 0.2 \mathrm{~kg} /$ $\mathrm{m}^{2}$ (mean $\pm \mathrm{SEM}$ )] were recruited. The main criteria for exclusion were use of medication, blood donation, or use of antibiotics in the past three months, gastrointestinal surgery or dysfunction, inflammatory diseases, and diabetes mellitus. Approval was obtained from the Medical Ethics Committee of the 'Beoordeling Ethiek Biomedisch Onderzoek' foundation, Assen, The Netherlands. Each subject gave written informed consent for the study. This trial was registered at trialregister.nl as NTR3020.

\section{Experimental design}

In the overall study design, addressing two different research questions, four different wheat-based products were tested. To increase clarity and be able to focus on the results of one of these questions, only two meals are described in this paper. A description of the other products and the results can be found elsewhere [19]. The study was performed in a randomized, crossover manner, with at least 1 week between each study day. The subjects were asked to refrain from consuming foods naturally high in ${ }^{13} \mathrm{C}$, like cane sugar, corn products, and pineapple, for 3 days preceding the experiments and from alcohol consumption and strenuous exercise for $24 \mathrm{~h}$ before each study day. Food intake on the day before each study day was individually standardized. To minimize variation, a standard evening meal was provided at the commercial research facility (QPS Netherlands B.V.), where the participants stayed overnight. In the evening, a venous catheter was inserted in each forearm for blood collection and for infusion of the tracer D- $\left[6,6-{ }^{2} \mathrm{H}_{2}\right]$ glucose $\left(98 \%{ }^{2} \mathrm{H}\right.$ atom percent excess, Isotec) $[20,21]$. Subjects fasted overnight, but were allowed to drink water. In the morning $(t=-122 \mathrm{~min})$, a bolus of $26.7 \mathrm{~mL}$ D- $\left[6,6-{ }^{2} \mathrm{H}_{2}\right]$ glucose solution $(80 \times 0.07 \mathrm{mg} / \mathrm{kg}$ body weight) was injected within $2 \mathrm{~min}$, and a continuous infusion of $0.07 \mathrm{mg} / \mathrm{kg}$ body weight D-[6,6- $\left.{ }^{2} \mathrm{H}_{2}\right]$ glucose per min was started $(t=-120 \mathrm{~min})$ and maintained for $8 \mathrm{~h}$ (until $t=360 \mathrm{~min}$ ). The bolus amount was $80 \times$ the infusion rate over $1 \mathrm{~min}$, according to the paper of Tissot et al [20]. The infusion rate over $1 \mathrm{~min}$ was $0.07 \mathrm{mg} / \mathrm{kg}$ BW [21], to reach a good steady state. So the continuous 
Fig. 1 Simplified schematic time line of each study day. Blood was collected at 18 time points, indicated by inverted triangle. Also, several breath and urine samples were collected during each study day

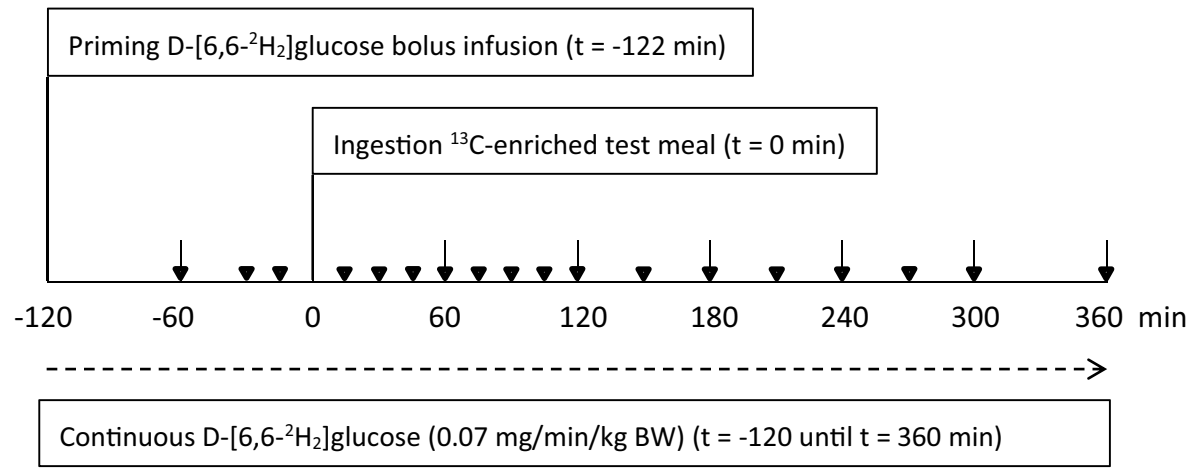

infusion contained $4.2 \mathrm{mg} / \mathrm{kg} \mathrm{BW}$ per $60 \mathrm{~min}$, administered at a desired infusion rate of $20 \mathrm{~mL} / \mathrm{h}$, resulting in the concentration of $0.21 \mathrm{mg} / \mathrm{mL} / \mathrm{kg} \mathrm{BW}$. The bolus had the same concentration, and therefore, to administer $80 \times 0.07 \mathrm{mg} /$ $\mathrm{kg} \mathrm{BW}$ an amount of $26.7 \mathrm{~mL}$ was administered.

Two hours after the start of the infusion the test meal was ingested ( $t=0 \mathrm{~min})$. Figure 1 shows a simplified time line of each study day. Water $(150 \mathrm{~mL})$ was provided hourly, starting at $t=120 \mathrm{~min}$. During the study period physical activity was limited.

\section{Test meals}

Two types of wheat bread were prepared (TNO, Zeist, The Netherlands), with the same composition, but a different structure, due to different milling and bread making processes; a kernel bread (KB) prepared with flour and $85 \%$ broken wheat kernels, and a control bread (CB) made from wheat flour, combined with wheat bran, to obtain the same dietary fiber content as in the KB.

To provide the necessary ingredients, unlabeled $\left(1.085\right.$ at. $\left.\%{ }^{13} \mathrm{C}\right)$ wheat grains [T. aestivum var Capo, grown in Austria] were milled in different ways; by conventional roller-milling the wheat kernels were milled to obtain refined white flour and wheat bran, and broken wheat kernels were obtained using a breaker mill. For ${ }^{13} \mathrm{C}$-enrichment of the products, ${ }^{13} \mathrm{C}$-labeled wheat [T. aestivum var Paragon $\left(1.359\right.$ at. $\left.\left.\%{ }^{13} \mathrm{C}\right)\right]$, cultured in a ${ }^{13} \mathrm{CO}_{2}$ enriched atmosphere, was used. A small part of the ${ }^{13} \mathrm{C}$-labeled wheat kernels was milled to obtain a fine wholemeal wheat flour, and the other part was broken to obtain broken kernels that were similar to the unlabeled broken kernels.

CB was prepared with $1446 \mathrm{~g}$ unlabeled white wheat flour, $240 \mathrm{~g}{ }^{13} \mathrm{C}$-labeled wholemeal wheat flour, $314 \mathrm{~g}$ wheat bran, $1300 \mathrm{~g}$ water, $33.4 \mathrm{~g}$ yeast, $36 \mathrm{~g}$ salt, $3 \mathrm{~g}$ malt, and $70 \mathrm{ppm}$ ascorbic acid. After kneading, the dough was left to rise for $30 \mathrm{~min}$, molded, and left to rise for $60 \mathrm{~min}$. $\mathrm{KB}$ was prepared with $264 \mathrm{~g}$ unlabeled white wheat flour, $36 \mathrm{~g}{ }^{13} \mathrm{C}$-labeled wholemeal wheat flour, $1496 \mathrm{~g}$ unlabeled broken wheat kernels, and $204 \mathrm{~g}{ }^{13} \mathrm{C}$-labeled broken wheat kernels. All broken kernels were soaked in $1000 \mathrm{~g}$ water overnight at $10{ }^{\circ} \mathrm{C}$. The following day, the soaked kernels were mixed with the flour, $230 \mathrm{~g}$ water, $33.4 \mathrm{~g}$ yeast, $36 \mathrm{~g}$ salt, $3 \mathrm{~g}$ malt, and $70 \mathrm{ppm}$ ascorbic acid. The resulting dough was left to rise for $30 \mathrm{~min}$, molded, and left to rise for $50 \mathrm{~min}$. Subsequently, the breads were baked for $30 \mathrm{~min}$ at $240{ }^{\circ} \mathrm{C}$. Bread slices were stored at $-20{ }^{\circ} \mathrm{C}$ until use.

All test meals provided $50 \mathrm{~g}$ available carbohydrates; for the $\mathrm{CB}$, the portion size was $138 \mathrm{~g}$ and for the KB $137 \mathrm{~g}$. The breads were consumed together with $10 \mathrm{~g}$ light margarine (4 $\mathrm{g}$ fat), 2 slices lean ham ( $5 \mathrm{~g}$ fat, $6 \mathrm{~g}$ protein), and $250 \mathrm{~mL}$ tap water within $20 \mathrm{~min}$. We assume that the digestibility of starch from both test products is similarly affected by this addition.

\section{Bread characterization}

Starch, dietary fiber, and moisture content were determined at Eurofins Analytico Food, The Netherlands. To quantify starch fractions $\left(\mathrm{G}_{\mathrm{T}}, \mathrm{G}_{\mathrm{RA}}, \mathrm{G}_{\mathrm{SA}}, \mathrm{G}_{\mathrm{TA}}\right.$, and $\left.\mathrm{RS}\right)$ of the test meals in vitro, an adapted version of the Englyst method [22] was used [23].

Particle size distribution of the broken kernels was determined by sieve analysis in duplicate.

Bread products volume $(\mathrm{mL})$ was determined in triplicate by rapeseed displacement (AACCI Method 10-05.01 [24]) and, together with the bread weight ( $\mathrm{g})$, the product overall specific volume $(\mathrm{mL} / \mathrm{g})$ and density $(\mathrm{g} / \mathrm{mL})$ were obtained.

Breads were further characterized using microscopy and X-ray microtomography (XRT, porosity). A detailed description of both techniques can be found in Online Resource 1.

\section{Sample collection}

Blood was collected into several blood collection tubes (BD Diagnostics): $2 \mathrm{~mL}$ fluoride tubes $(\mathrm{NaF})$ for glucose and bile acid measurements, $3 \mathrm{~mL}$ EDTA tubes $[+30 \mu \mathrm{L}$ DPP-4 inhibitor (Millipore)] for GIP, GLP-1, glucagon, 
and insulin determination, and $3 \mathrm{~mL}$ lithium/heparin tubes (CCK). Three basal blood samples were collected ( $t=-60,-30,-15 \mathrm{~min})$, and postprandial samples were drawn every $15 \mathrm{~min}$ for $2 \mathrm{~h}$, every $30 \mathrm{~min}$ for an additional $3 \mathrm{~h}$, and once after $6 \mathrm{~h}$. To obtain heparin plasma, blood was collected at $t=-60, t=-15 \mathrm{~min}$ and then every $30 \mathrm{~min}$ for the first $3 \mathrm{~h}$, and hourly for the last $3 \mathrm{~h}$. After centrifugation $\left(1300 \times g\right.$ for $10 \mathrm{~min}$ at $\left.4{ }^{\circ} \mathrm{C}\right)$, plasma aliquots were stored at $-20{ }^{\circ} \mathrm{C}(\mathrm{NaF}$ and EDTA plasma) or $-80{ }^{\circ} \mathrm{C}$ (heparin plasma) until analysis.

Breath samples were collected by breathing through a straw into $10 \mathrm{~mL}$ Exetainer ${ }^{\circledR}$ vials (Labco Limited). Two basal breath samples were collected $(t=-30, t=-5 \mathrm{~min})$, and after the test meal, a sample was taken every $30 \mathrm{~min}$ until $t=360 \mathrm{~min}$.

To get an impression about the impact of the breads on appetite, subjects were asked to rate their feeling of appetite (hunger) using a visual analog scale (VAS) at $15 \mathrm{~min}$ before and hourly after the test meal, although the number of subjects $(n=10)$ is insufficient to detect differences in these subjective measures [25]. At the same time points, their feeling and extent of discomfort (abdominal pain, flatulence, other complaints) was recorded ( $0=$ no complaints, $3=$ severe complaints). Shortly after consumption of the meal, the subjects scored (VAS) how tasty the meal was.

\section{Measurement of plasma concentrations}

Plasma glucose concentrations were measured on a Roche/Hitachi Modular automatic analyzer (Roche Diagnostics, Hitachi) using a glucose hexokinase method. The within- and between-run CV were $\leq 2 \%$. The ARCHITECT $^{\circledR}$ insulin assay (Abbott Laboratories) was used to determine insulin concentrations in plasma. The total $\mathrm{CV}$ of this chemiluminescent microparticle immunoassay was $\leq 7 \%$. The glucagon assay was directed against the C-terminal of the glucagon molecule (antibody code no. 4305) and therefore measures glucagon of mainly pancreatic origin [26]. Total GIP was measured using the C-terminally directed antiserum (no. 80867) [27], which reacts fully with intact GIP (1-42) and the N-terminally truncated metabolite GIP (3-42). Total GLP-1 concentrations were determined as previously described [28], using a radioimmunoassay (antiserum no. 89390) specific for the C-terminal of the GLP-1 molecule and reacting equally with intact GLP-1 and the primary (N-terminally truncated) metabolite. The glucagon and incretin assays have detection limits of $<2 \mathrm{pmol} / \mathrm{L}$, and an intra-assay coefficient of variation of approximately $6 \%$. CCK was measured using antiserum no. 92128, which binds the bioactive forms of CCK with equal potency without cross-reactivity with any gastrin [29]. The detection limit of the CCK assay is
$0.1 \mathrm{pmol} / \mathrm{L}$, and the intra-assay coefficient of variation approximately $5 \%$.

\section{Measurement of plasma bile acids}

Fasting and postprandial concentrations of 15 individual BAs were determined using LC/MS: the primary BAs [cholic acid (CA) and chenodeoxycholic acid (CDCA)], the secondary BAs [deoxycholic acid (DCA), ursodeoxycholic acid (UDCA), and lithocholic acid (LCA)], as well as their glycine (G, glyco-) and taurine (T, tauro-) conjugates. The lower limit of quantitation (LOQ) was $0.05 \mu \mathrm{M}$. Concentrations of TCA, LCA, GLCA, TLCA, TDCA, UDCA, and TUDCA were below the LOQ. The intra- and inter-assay CV ranged from 1.6 to 11.3 and 4.4 to $13.3 \%$, respectively. For sample preparation, $250 \mu \mathrm{l}$ of internal standard solution was mixed with $25 \mu \mathrm{l}$ plasma and centrifuged at $15.900 \times g$ for $10 \mathrm{~min}$. The supernatant was transferred into a new vial, evaporated under nitrogen at $40{ }^{\circ} \mathrm{C}$, and reconstituted in $100 \mu \mathrm{l}$ of $50 \%$ methanol. The solution was filtered with a $0.2-\mu \mathrm{m}$ centrifugal filter at $2000 \times g$ for $10 \mathrm{~min}$. After this step, the samples (injection volume $10 \mu \mathrm{l}$ ) were ready for analysis, using two different LC/MS systems. A detailed description of the systems and settings can be found in Online Resource 2.

\section{Analysis of isotopic enrichment (breath and plasma) and calculations}

Analysis of ${ }^{13} \mathrm{C}$ abundance in breath $\mathrm{CO}_{2}$ was performed using GC/IRMS (Delta Plus XL; Thermo Fisher Scientific) measuring the ${ }^{13} \mathrm{C} /{ }^{12} \mathrm{C}$ ratio versus the international standard Pee Dee Belemnite $\left(\delta^{13} \mathrm{C}_{\mathrm{PDB}}\right.$, in $\%$ ) .

Plasma sample preparation required for analysis of isotopic enrichment by GC (derivatization) is described in detail elsewhere [30, 31]. ${ }^{2} \mathrm{H}$ enrichment was measured by $\mathrm{GC} / \mathrm{MS}$ as previously described [30], and ${ }^{13} \mathrm{C} /{ }^{12} \mathrm{C}$ isotope ratio was measured using GC/C/IRMS as previously described [32], both with some modifications [33].

Calculation of glucose kinetics was performed as previously reported [34].

\section{Incremental areas under the curve (iAUC)}

To determine differences in glucose kinetics and plasma glucose, insulin, glucagon, incretin, $\mathrm{CCK}$, and bile acid concentrations, the 0-2 and 0-6 h iAUCs were calculated as previously described [34].

\section{Statistics}

Human data are presented as mean \pm SEM, $n=10$. Baseline-subtracted values are shown in the figures and were 
used in the analyses as well, for clarity, consistency, and comparison of variables. The overall study involved testing of four test meals. From the statistical analysis of the full experiment, we highlight only the comparisons involving the products of current interest. For parameters that result in individual points of a time curve, we fitted a model that accounts for the differences between the 10 subjects and the four occasions, the main effects of treatment and time, respectively, and the time $\times$ treatment interaction. Residual plots based on such a model were used to assess approximate normality and homogeneity of variances. Parameters that were not compatible with these assumptions were transformed before definitive analysis. Most variables were log-transformed, except for glucose (reciprocal values), VAS scores (angular transformation), $\mathrm{RaE}$, and ${ }^{13} \mathrm{CO}_{2}$ values (Poisson regression model on log scale).

We performed $F$ tests on time $\times$ treatment interaction effects to assess whether the four test meals gave rise to curves of a different shape. If the test resulted in a $P$ value $<0.05$, we tested differences between the meals for each time point. If there were no statistically significant differences in shapes, we tested overall differences between the meals based on the above model without the time $\times$ treatment interaction.

To assess summary measures such as iAUC, we fitted a model accounting for the differences in the means of the 10 subjects and the four occasions, and the main effects of treatment. Transformed data were used whenever residual plots showed incompatibility with normality and homogeneity assumptions. We performed an $F$ test to see whether there were differences between the meals. If this test resulted in a $P$ value $<0.05$, pairwise comparisons among the meals were conducted.

A Benjamini-Hochberg correction was applied on $P$ values from all partial tests to correct for multiple comparisons, resulting in a set of differences in which at most $5 \%$ were falsely selected $(P<0.0052$ for partial tests was considered significant). The analyses were performed with the software package GenStat, release 13. The within-subject relationship (correlation) between variables was tested by regression analysis according to the method of Bland and Altman [35]. Test meal differences (e.g., density, porosity) were assessed using a Student's $t$ test; a $P$ value $<0.05$ was considered significant. These analyses were performed using SPSS 20.0 for Windows (SPSS Inc., Chicago).

\section{Results}

\section{Characterization of test meals}

The breads ( $\mathrm{CB}$ and $\mathrm{KB}$, respectively) were comparable in amount of starch (36.2 and $36.4 \%$ ), dietary fiber (7.6 and
Table 1 In vitro quantification of starch fractions in the test meals

\begin{tabular}{lcccc}
\hline Starch fraction & \multicolumn{4}{l}{ Test meal/portion } \\
\cline { 2 - 5 } & CB total & KB total & KB kernel & KB crumb \\
\hline$\%$ & 100 & 100 & 100 & 100 \\
$\mathrm{G}_{\mathrm{T}}$ & 78.8 & 76.4 & 65.5 & 67.8 \\
$\mathrm{G}_{\mathrm{RA}}$ & 11.8 & 13.6 & 15.9 & 16.3 \\
$\mathrm{G}_{\mathrm{SA}}$ & 90.6 & 90.0 & 81.4 & 84.1 \\
$\mathrm{G}_{\mathrm{TA}}$ & 8.4 & 9.0 & 16.7 & 14.3 \\
$\mathrm{RS}$ &
\end{tabular}

$C B$ control bread, $G_{R A}$ rapidly available glucose $(20 \mathrm{~min}), G_{S A}$ slowly available glucose $(20-120 \mathrm{~min}), G_{T}$ total glucose (indicated as $100 \%), G_{T A}$ total available glucose $(120 \mathrm{~min}), K B$ kernel bread, $R S$ resistant starch

$8.3 \%$ ), and moisture content (38.6 and $37.8 \%)$. In vitro quantification of starch fractions showed similar digestive characteristics for $\mathrm{CB}$ and $\mathrm{KB}$ when a sample from the total bread was analyzed (Table 1).

A main difference between the two breads (Fig. 2a) was their density; CB had a density of $0.29 \pm 0.007 \mathrm{~g} /$ $\mathrm{mL}$ compared to $0.41 \pm 0.003 \mathrm{~g} / \mathrm{mL}$ for $\mathrm{KB}(P<0.05)$. The difference in density was clearly visible in the product structure (Fig. 2b). In the case of KB, $85 \%$ of the wheat material consisted of broken kernels. The majority $(72.6 \%)$ of the broken kernels had a particle size between 1680 and $2800 \mu \mathrm{m}$ as measured by pan sieving. Both visual evaluation and microscopy confirmed that the KB structure consisted of broken wheat kernels with a particle size of 1 to several mm (Fig. 2b). Light microscopy with starch (lugol; blue) and protein staining (Ponceau 2R; red) (Fig. 2c) showed that CB had a porous structure and the thin cell walls were dominated by a continuous phase of starch granules in blue. In this matrix bran particles were clearly visible as clusters of red aleurone cells aligned on the outer side by pericarp layers. An apparent difference was the presence of broken wheat kernels in which no starch granules (blue) were observed (Fig. 2c). Apparently, the matrix was governed by proteins (in red) embedding the starch granules.

A description of the porosity measurements of both breads using XRT can be found in Online Resource 1.

\section{Postprandial glucose and insulin response}

Postprandial glucose concentrations were similar after the consumption of $\mathrm{CB}$ and KB (Fig. 3a; Table 2). The insulin response was lower after $\mathrm{KB}$ consumption compared to $\mathrm{CB}$ at $t=60 \min (P=0.002)$ (Fig. 3b), which resulted in a $31 \%$ smaller iAUC $(0-2 \mathrm{~h})$ compared with CB intake (NS, $P=0.011)$. 
Fig. 2 Pictures of ${ }^{13} \mathrm{C}$-enriched control and kernel bread: a overview; b stereo microscopy; c light microscopy with starch (lugol; blue) and protein (Ponceau $2 \mathrm{R}$; red) staining
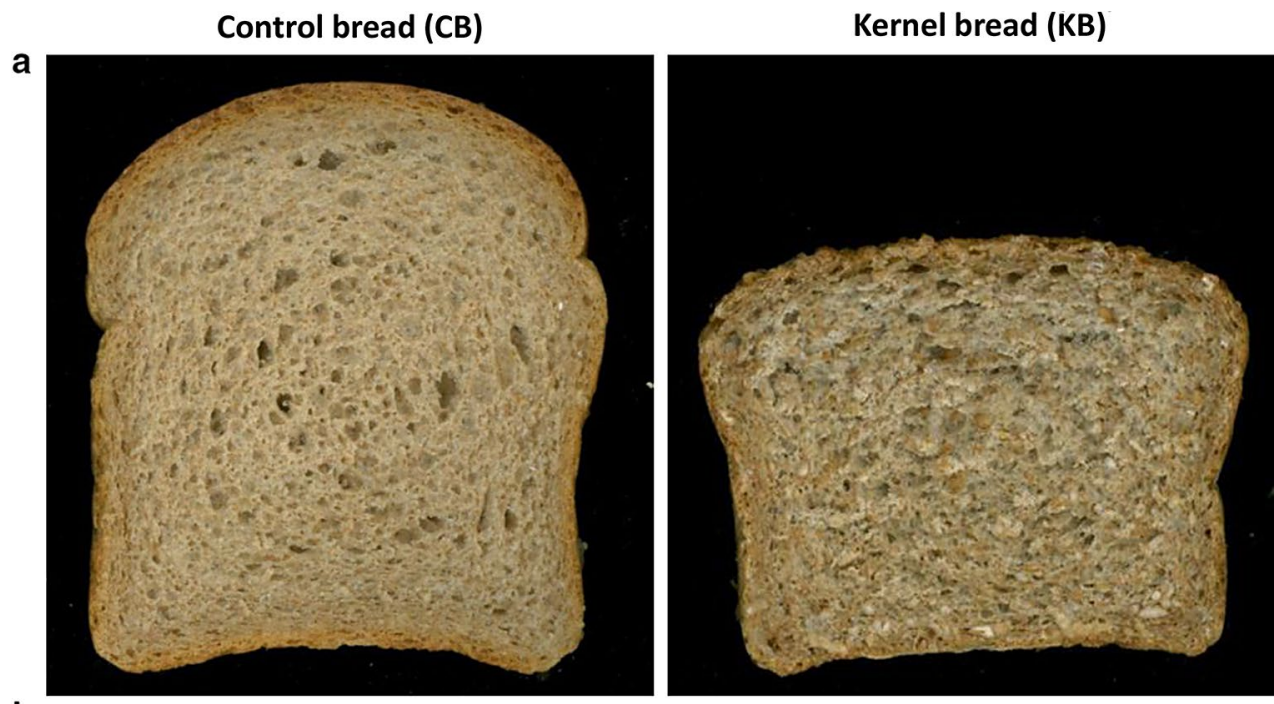

b
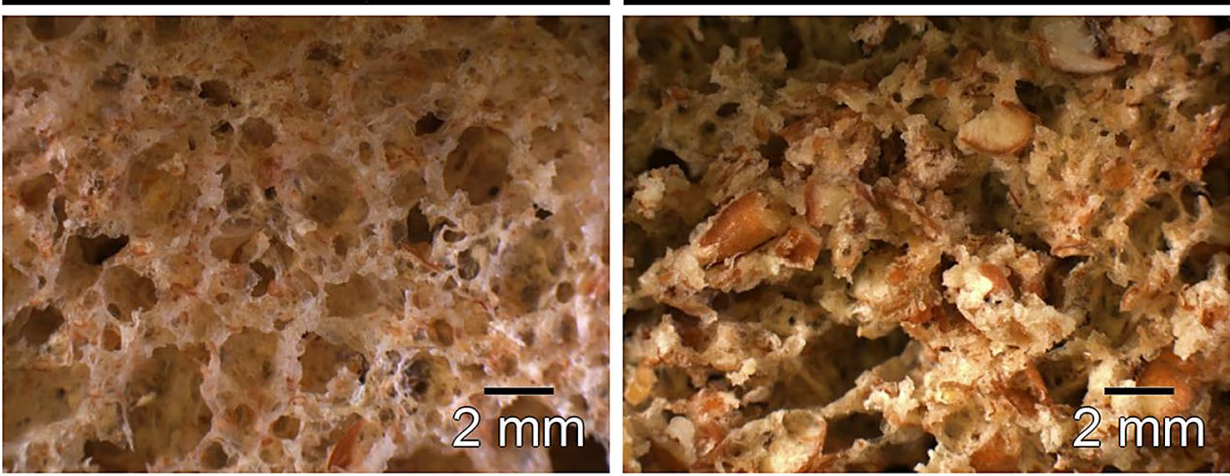

C
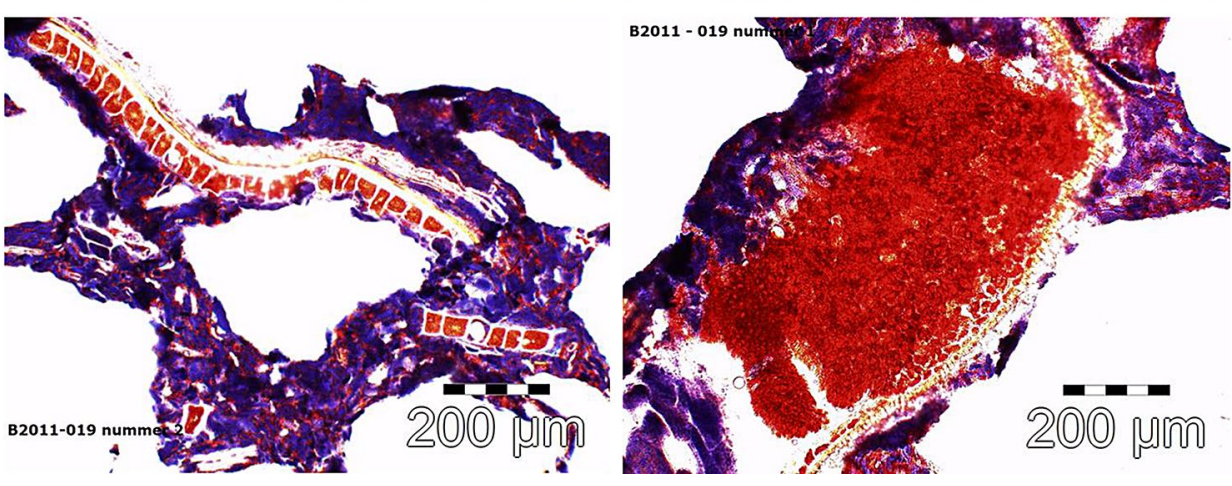

\section{Glucose kinetics}

The $\mathrm{RaE}$ was similar after $\mathrm{CB}$ and $\mathrm{KB}$ consumption (Fig. 4a), except for $t=120 \mathrm{~min}$, where RaE was higher after CB intake $(P=0.005)$. EGP was not significantly different after consumption of $\mathrm{CB}$ and $\mathrm{KB}$. The rate at which glucose was cleared from the circulation (GCR) was also similar (Fig. 4b; Table 2).

\section{Postprandial incretin, glucagon, and CCK response}

The average postprandial GIP response was somewhat higher after $\mathrm{CB}$ compared with $\mathrm{KB}$ intake (Fig. 5a;
Table 2), but a significant difference was only found at $t=120 \mathrm{~min}(P<0.005)$. The average GLP-1 response was higher after $\mathrm{CB}$ compared to $\mathrm{KB}$ consumption at each time point (Fig. $5 \mathrm{~b}$ ), resulting in a difference in the $0-2$ and $0-6 \mathrm{~h}$ iAUC (Table $2, P<0.005$ ). Differences between time points could, however, not be determined, as time $\times$ treatment interaction failed to reach significance $(P=0.073)$.

The postprandial glucagon response appeared higher after $\mathrm{CB}$ consumption, but no partial test (CB-KB) could be performed for iAUC. Also, differences between meals at individual time points could not be tested, as there was no time $\times$ treatment interaction $(P=0.9991)$. 

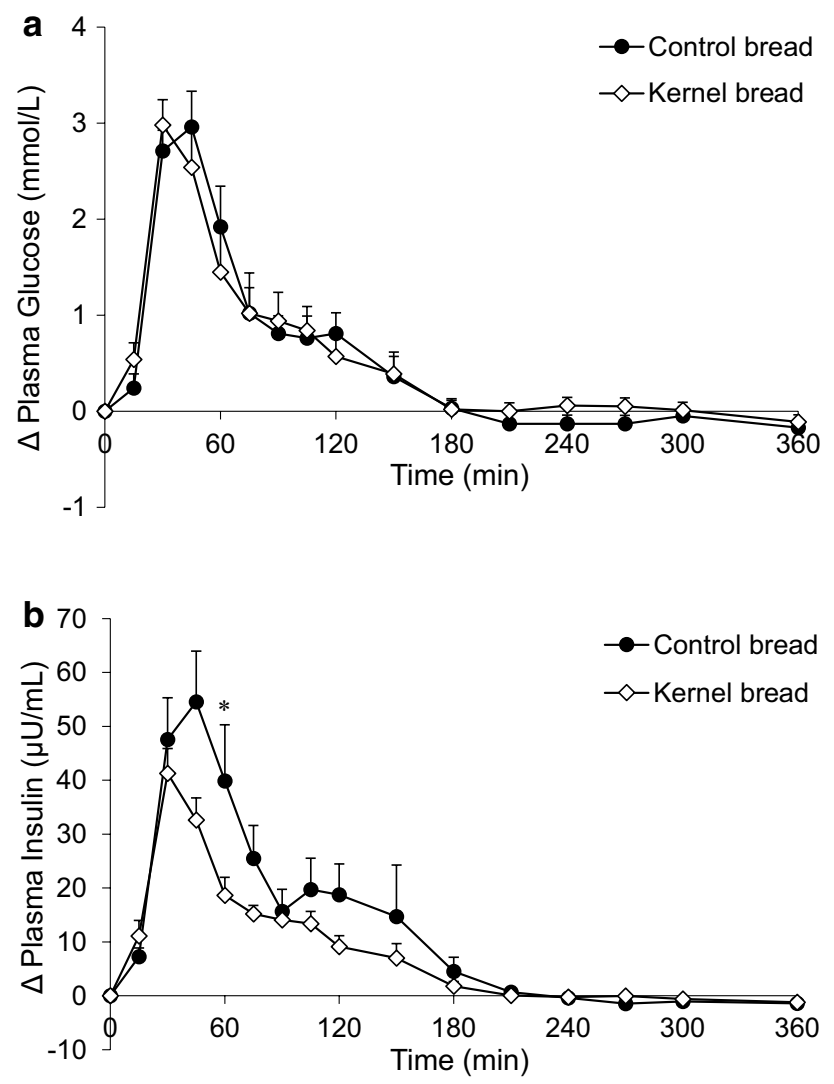

Fig. 3 Mean $( \pm$ SEM $)$ changes from baseline in a plasma glucose concentrations and b plasma insulin concentrations, after ingestion of $138 \mathrm{~g}{ }^{13} \mathrm{C}$-enriched control bread (filled circle) and $137 \mathrm{~g}$ ${ }^{13} \mathrm{C}$-enriched kernel bread (open diamond) in healthy men $(n=10)$. There was no significant time $\times$ treatment interaction for glucose $(P=0.1773)$, but there was for insulin $(P<0.0001)$. Asterisk significantly different between treatments per time point (after BenjaminiHochberg correction)

There was a slight increase in CCK concentrations in response to the test meals, which seemed somewhat lower after the KB from 90 min postprandial (Fig. 6a; Table 2), although differences were not significant (iAUC 0-6 h, $P=0.03$ ).

\section{Postprandial bile acid response}

The postprandial pattern of glycine and taurine conjugated BAs in plasma was intra-individually identical, with the highest concentrations for GCDCA, followed by either GDCA or GCA. The unconjugated BAs (primary and secondary) also responded in the same way within each person per test period. Therefore, by summing up concentrations, individual BAs were grouped as conjugated and unconjugated BAs, and together they formed the total BA response (Fig. 6b). Unconjugated BAs in plasma showed a decrease after test meal consumption (Fig. 6c), whereas the conjugated BAs increased postprandial and peaked around $t=30$ min (Fig. 6d). After CB consumption, conjugated BAs showed a second peak around $t=120 \mathrm{~min}$. Due to the great inter-individual variation in postprandial responses, $F$ tests did not result in significant $P$ values, so differences between $\mathrm{CB}$ and $\mathrm{KB}$ could not be tested.

\section{${ }^{13} \mathrm{CO}_{2}$ excretion in breath}

${ }^{13} \mathrm{CO}_{2}$ excretion in breath, reflecting the rate of oxidation of the ${ }^{13} \mathrm{C}$-labeled substrate, was higher after $\mathrm{CB}$ consumption at $t=210 \min (P=0.0014)$. The time to peak was not different after the meals, but the peak value was significantly higher after $\mathrm{CB}$ consumption $(P=0.005)$ (Table 2$)$.

\section{Correlations}

Correlations between several variables (all time points, 0-6 h; $P<0.05$ ) were determined (Table 3). RaE and GIP were very well correlated, especially for $\mathrm{CB}$ (CB, $r=0.84 ; \mathrm{KB}, r=0.71)$. RaE and GLP-1 showed a moderate correlation ( $\mathrm{CB}, r=0.70 ; \mathrm{KB}, r=0.58)$. The correlation between GLP-1 and conjugated BAs was moderate for $\mathrm{CB}(r=0.60)$ and lower for $\mathrm{KB}(r=0.39)$. Total BAs with GLP-1 showed similar correlation coefficients (CB, $r=0.53 ; \mathrm{KB}, r=0.43$ ).

\section{Rated appetite, discomfort, and liking of test meal}

The subjective sensation of appetite (hunger), as determined hourly using a VAS, was similar after consumption of $\mathrm{CB}$ and $\mathrm{KB}$ (data not shown). Occasional mild complaints about flatulence were not meal type related. The liking of the test meal was rated by using a VAS $(0=$ not tasty, $100=$ very tasty $)$. The resulting scores $(\mathrm{CB}=57$, $\mathrm{KB}=33$ ) indicate that the $\mathrm{KB}$ was not well appreciated by the subjects.

\section{Discussion}

This paper describes the glucose kinetics and metabolic effects in healthy men after consumption of control bread (CB) and $85 \%$ broken kernel bread (KB). We expected that consumption of $\mathrm{KB}$ would result in a low glycemic response due to slower digestion of starch in the larger wheat kernel particles $[17,18]$. However, the postprandial glycemic response did not differ after consumption of our breads. Although a similar glycemic response does not exclude a difference in in vivo starch digestibility due to possible differences in GCR [33, 34] or EGP, the present study found no pronounced differences in glucose kinetics. The RaE, reflecting intestinal glucose uptake, as well 
Table 2 Indices reflecting the metabolic response after ingestion of $138 \mathrm{~g}{ }^{13} \mathrm{C}$-enriched control bread and $137 \mathrm{~g}$ ${ }^{13} \mathrm{C}$-enriched kernel bread in healthy men

\begin{tabular}{|c|c|c|c|c|c|}
\hline & Fasting values & Peak values & Time to peak (min) & iAUC (0-2 h) & iAUC $(0-6$ h) \\
\hline \multicolumn{6}{|c|}{ Glucose (mmol/L) } \\
\hline CB & $5.1 \pm 0.1$ & $8.3 \pm 0.3$ & $40.5 \pm 3.2$ & $163.2 \pm 20.5$ & $197.0 \pm 23.4$ \\
\hline $\mathrm{KB}$ & $5.0 \pm 0.1$ & $8.2 \pm 0.3$ & $34.5 \pm 2.3$ & $159.4 \pm 30.1$ & $195.4 \pm 35.4$ \\
\hline \multicolumn{6}{|c|}{ Insulin $(\mu \mathrm{U} / \mathrm{mL})$} \\
\hline $\mathrm{CB}$ & $4.9 \pm 0.5$ & $69.9 \pm 10.5$ & $43.5 \pm 3.5$ & $3290.9 \pm 528.8$ & $4193.0 \pm 936.6$ \\
\hline KB & $5.0 \pm 0.5$ & $48.7 \pm 4.5$ & $36.0 \pm 2.4$ & $2262.1 \pm 205.4$ & $2707.6 \pm 292.9$ \\
\hline \multicolumn{6}{|c|}{ Glucagon (pmol/L) } \\
\hline $\mathrm{CB}$ & $8.3 \pm 1.0$ & $15.8 \pm 1.7$ & $175.5 \pm 33.4$ & $272.9 \pm 84.6$ & $980.5 \pm 163.4$ \\
\hline KB & $10.4 \pm 1.2$ & $16.8 \pm 2.3$ & $136.5 \pm 38.2$ & $207.1 \pm 89.4$ & $706.8 \pm 199.9$ \\
\hline \multicolumn{6}{|c|}{ GIP (pmol/L) } \\
\hline $\mathrm{CB}$ & $9.2 \pm 1.8$ & $84.9 \pm 10.5$ & $93.0 \pm 13.6$ & $4904.6 \pm 426.7$ & $9089.2 \pm 1137.8$ \\
\hline $\mathrm{KB}$ & $12.4 \pm 1.6$ & $74.5 \pm 11.0$ & $84.0 \pm 13.5$ & $4494.8 \pm 743.1$ & $7169.4 \pm 989.0$ \\
\hline \multicolumn{6}{|c|}{ GLP-1 (pmol/L) } \\
\hline $\mathrm{CB}$ & $15.5 \pm 1.4$ & $30.9 \pm 2.1$ & $86.3 \pm 15.7$ & $949.9 \pm 95.0$ & $2019.9 \pm 183.0$ \\
\hline KB & $18.3 \pm 1.6$ & $30.2 \pm 1.8$ & $76.5 \pm 16.9$ & $594.7 \pm 102.4^{\mathrm{a}}$ & $1167.0 \pm 295.3^{\mathrm{a}}$ \\
\hline \multicolumn{6}{|c|}{$\mathrm{RaT}$ (mg/kg min) } \\
\hline $\mathrm{CB}$ & $2.0 \pm 0.1$ & $6.5 \pm 0.3$ & $57.0 \pm 14.5$ & $39.1 \pm 1.4$ & $88.1 \pm 1.6$ \\
\hline KB & $2.0 \pm 0.0$ & $6.8 \pm 0.3$ & $36.0 \pm 6.0$ & $38.2 \pm 1.1$ & $85.1 \pm 1.4$ \\
\hline \multicolumn{6}{|c|}{$\mathrm{RaE}(\mathrm{mg} / \mathrm{kg} \min )$} \\
\hline $\mathrm{CB}$ & $0 \pm 0$ & $4.9 \pm 0.2$ & $66.0 \pm 14.9$ & $49.7 \pm 1.6$ & $95.9 \pm 4.7$ \\
\hline KB & $0 \pm 0$ & $4.9 \pm 0.2$ & $42.0 \pm 12.0$ & $46.9 \pm 1.7$ & $89.1 \pm 1.8$ \\
\hline \multicolumn{6}{|c|}{$\operatorname{EGP}(\mathrm{mg} / \mathrm{kg} \min )^{\mathrm{b}}$} \\
\hline $\mathrm{CB}$ & $2.0 \pm 0.1$ & $0.9 \pm 0.2$ & $111.0 \pm 12.1$ & $43.4 \pm 9.3$ & $157.8 \pm 26.7$ \\
\hline $\mathrm{KB}$ & $2.0 \pm 0.0$ & $0.9 \pm 0.2$ & $117.0 \pm 23.7$ & $40.8 \pm 8.8$ & $151.4 \pm 24.3$ \\
\hline \multicolumn{6}{|c|}{ GCR (mL/kg min) } \\
\hline $\mathrm{CB}$ & $2.5 \pm 0.1$ & $6.4 \pm 0.2$ & $100.5 \pm 12.5$ & $15.6 \pm 1.5$ & $32.7 \pm 1.7$ \\
\hline KB & $2.5 \pm 0.1$ & $6.1 \pm 0.3$ & $85.5 \pm 12.3$ & $15.5 \pm 1.9$ & $30.9 \pm 2.9$ \\
\hline \multicolumn{6}{|c|}{${ }^{13} \mathrm{CO}_{2}(\%$ dose $/ \mathrm{h})$} \\
\hline $\mathrm{CB}$ & $0 \pm 0$ & $7.7 \pm 0.2$ & $228.0 \pm 9.2$ & $4.3 \pm 0.3$ & $31.7 \pm 0.7$ \\
\hline $\mathrm{KB}$ & $0 \pm 0$ & $7.2 \pm 0.2^{\mathrm{a}}$ & $237.0 \pm 7.0$ & $4.2 \pm 0.2$ & $30.0 \pm 0.8$ \\
\hline \multicolumn{6}{|c|}{ CCK (pmol/L) } \\
\hline $\mathrm{CB}$ & $0.5 \pm 0.1$ & $2.6 \pm 0.3$ & $115.5 \pm 10.5$ & $142.4 \pm 5.7$ & $295.0 \pm 26.4$ \\
\hline KB & $0.6 \pm 0.1$ & $2.2 \pm 0.1$ & $126.0 \pm 14.0$ & $132.0 \pm 13.6$ & $243.0 \pm 26.2$ \\
\hline \multicolumn{6}{|c|}{ Total BA $(\mu \mathrm{mol} / \mathrm{L})$} \\
\hline $\mathrm{CB}$ & $2.1 \pm 0.4$ & $4.3 \pm 0.7$ & $61.5 \pm 19.7$ & $93.0 \pm 23.3$ & $171.2 \pm 40.9$ \\
\hline KB & $2.1 \pm 0.6$ & $4.2 \pm 0.7$ & $63.0 \pm 21.1$ & $80.3 \pm 18.1$ & $139.8 \pm 42.8$ \\
\hline \multicolumn{6}{|c|}{ Conjugated BA $(\mu \mathrm{mol} / \mathrm{L})$} \\
\hline $\mathrm{CB}$ & $1.2 \pm 0.3$ & $3.6 \pm 0.6$ & $63.0 \pm 19.3$ & $110.8 \pm 21.3$ & $216.2 \pm 43.4$ \\
\hline $\mathrm{KB}$ & $1.0 \pm 0.3$ & $3.3 \pm 0.4$ & $64.5 \pm 20.7$ & $108.7 \pm 24.9$ & $204.5 \pm 43.8$ \\
\hline \multicolumn{6}{|c|}{ Unconjugated $\mathrm{BA}(\mu \mathrm{mol} / \mathrm{L})^{\mathrm{b}}$} \\
\hline $\mathrm{CB}$ & $0.9 \pm 0.3$ & $0.2 \pm 0.1$ & $211.5 \pm 38.0$ & $47.7 \pm 26.9$ & $185.2 \pm 96.9$ \\
\hline $\mathrm{KB}$ & $1.1 \pm 0.5$ & $0.2 \pm 0.0$ & $257.3 \pm 41.3$ & $60.2 \pm 40.5$ & $260.2 \pm 160.9$ \\
\hline
\end{tabular}

Values are mean $\pm \mathrm{SEM}, n=10$

$B A$ bile acid, $C B$ control bread, $C C K$ cholecystokinin, $E G P$ endogenous glucose production, $G C R$ glucose clearance rate, GIP glucose-dependent insulinotropic polypeptide, $G L P-1$ glucagon-like peptide-1, iAUC incremental area under the curve, $K B$ kernel bread, $R a E$ rate of appearance of exogenous glucose, $R a T$ rate of appearance of total glucose

a Significantly different from control bread

b Because EGP and unconjugated BAs were suppressed after the test meals, the nadir values and time to nadir are presented. Also, the area beneath baseline (dAUC) was calculated using mirrored data 

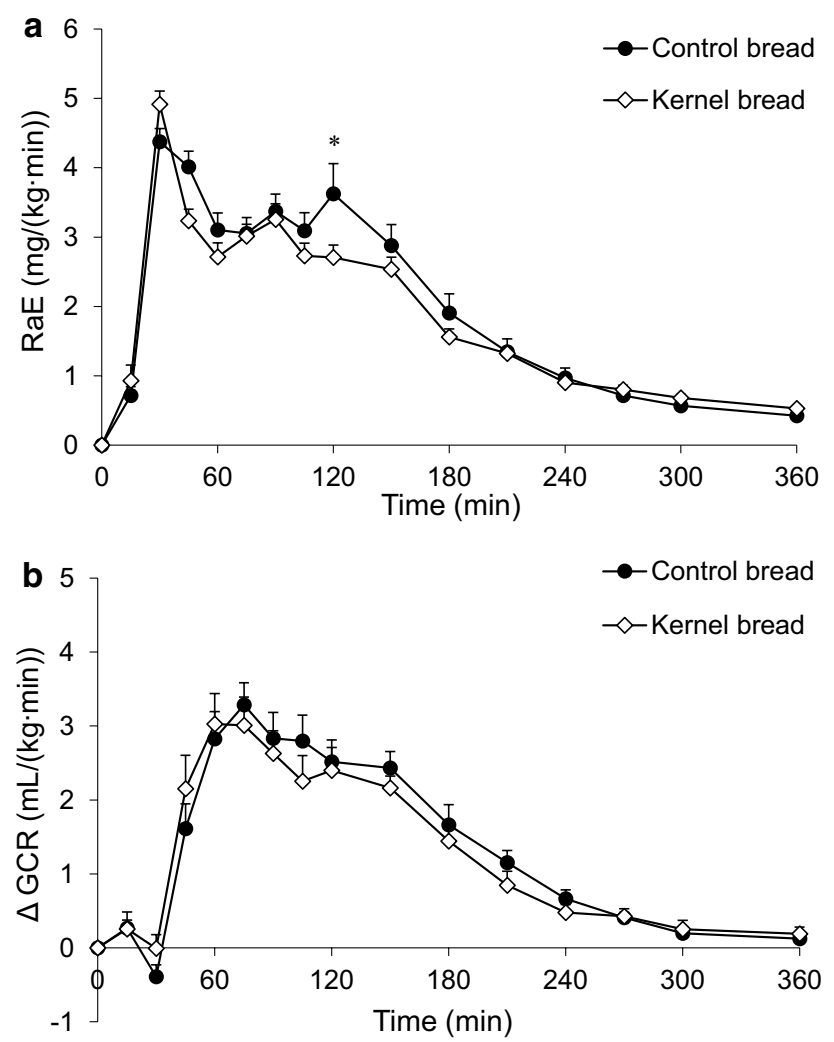

Fig. 4 Mean $( \pm$ SEM) of a $\mathrm{RaE}$ and $\mathbf{b}$ changes from baseline in $\mathrm{GCR}$, after ingestion of $138 \mathrm{~g}{ }^{13} \mathrm{C}$-enriched control bread (filled circle) and $137 \mathrm{~g}{ }^{13} \mathrm{C}$-enriched kernel bread (open diamond) in healthy men $(n=10)$. There was a significant time $\times$ treatment interaction for $\operatorname{RaE}(P<0.0001)$ and GCR $(P=0.0002)$. Asterisk significantly different between treatments per time point (after Benjamini-Hochberg correction). $R a E$ rate of appearance of exogenous glucose, $G C R$ glucose clearance rate

as the GCR and EGP, was similar after KB compared to CB. However, a clear difference in GLP-1 responses was observed after consumption of the test meals.

The use of intact grain kernels in bread formulations has been reported to reduce the glucose response by limiting starch gelatinization and forming a physical barrier for $\alpha$-amylase, reducing amylolysis [36]. For instance, the incorporation of $80 \%$ preboiled whole wheat kernels $[37,38]$ showed the expected lowering effect of incorporated kernels on the glycemic response. However, the use of intact kernels per se does not necessarily induce a low GI, as incorporation of oat kernels showed less effect on glycemia [38]. Considering the palatability of the breads, we chose to incorporate broken wheat kernels and not intact kernels in $\mathrm{KB}$, because the replacement of flour (50 and $75 \%$ [18]) with cracked wheat was also previously reported to result in a reduction in GI. The broken kernels were soaked overnight to prevent difficulties in chewing. Even though the broken kernels in KB were still clearly visible, during preparation of the dough the soaked
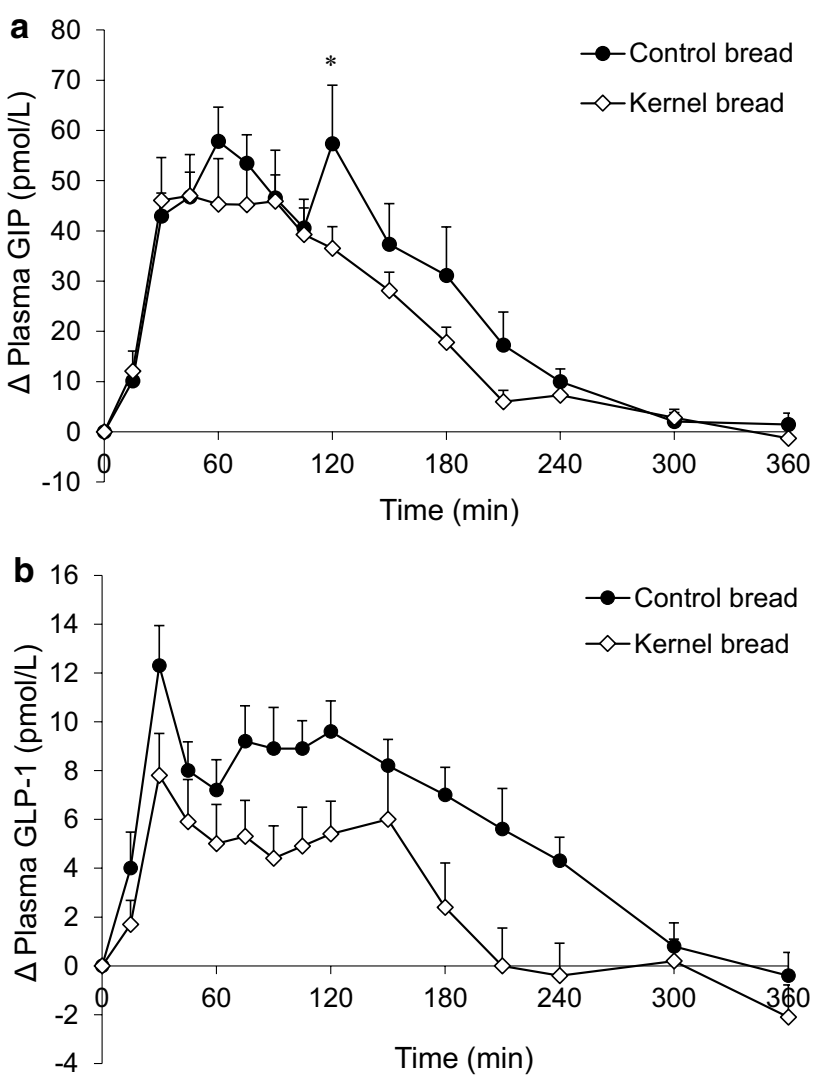

Fig. 5 Mean $( \pm$ SEM) changes from baseline in a plasma GIP concentrations and b plasma GLP-1 concentrations, after ingestion of $138 \mathrm{~g}{ }^{13} \mathrm{C}$-enriched control bread (filled circle) and $137 \mathrm{~g}$ ${ }^{13} \mathrm{C}$-enriched kernel bread (open diamond) in healthy men $(n=10)$. There was a significant time $\times$ treatment interaction for GIP $(P=0.036)$, but not for GLP-1 $(P=0.073)$. Asterisk significantly different between treatments per time point (after Benjamini-Hochberg correction). GIP glucose-dependent insulinotropic polypeptide, $G L P$-1 glucagon-like peptide-1

kernels were thoroughly kneaded together with other ingredients, which might have further destructured the kernels, thus increasing starch accessibility to amylolysis. Breads were extensively characterized to document the impact of addition of broken kernels. The porosity, the average size of air cell diameter, and air cell distribution were not significantly different between both breads. However, KB did have a higher density, which in itself is a characteristic that could give rise to a lower glycemic response [39]. Moreover, the average air cell wall thickness of $\mathrm{KB}$ was significantly increased compared to $\mathrm{CB}$, but these differences were apparently not large enough to evoke a difference in glucose response or kinetics.

Despite the similarities in the glycemic response, the GLP-1 response was much lower after KB consumption compared to $\mathrm{CB}$ (iAUC, $P<0.005$ ). Nutrient ingestion is the main stimulus to L cells, which are described as an open type cell, enabling direct stimulation and release of 

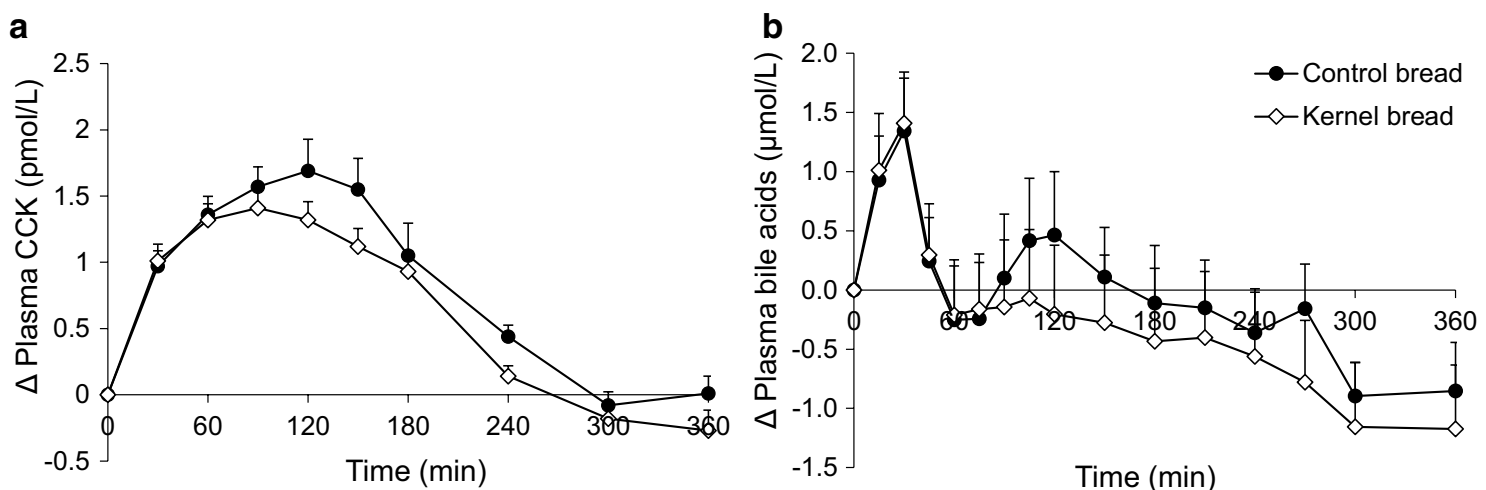

Time (min)

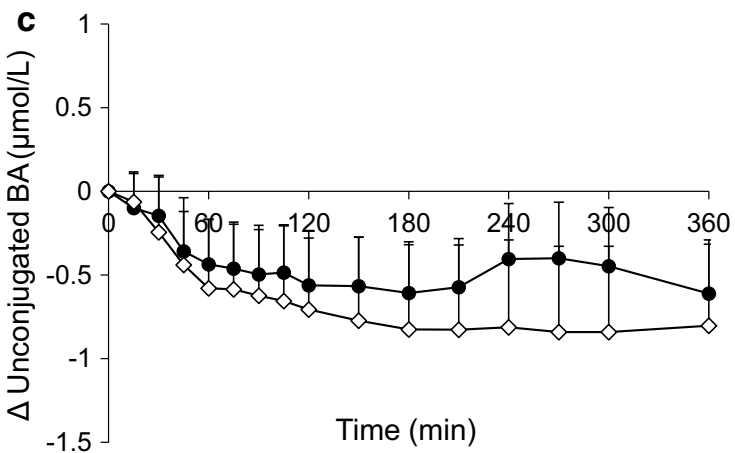

Fig. 6 Mean $( \pm$ SEM $)$ changes from baseline in a plasma CCK concentrations b total plasma BA concentrations c unconjugated BA concentrations and $\mathbf{d}$ conjugated BA concentrations, after ingestion of $138 \mathrm{~g}{ }^{13} \mathrm{C}$-enriched control bread (filled circle) and $137 \mathrm{~g}$

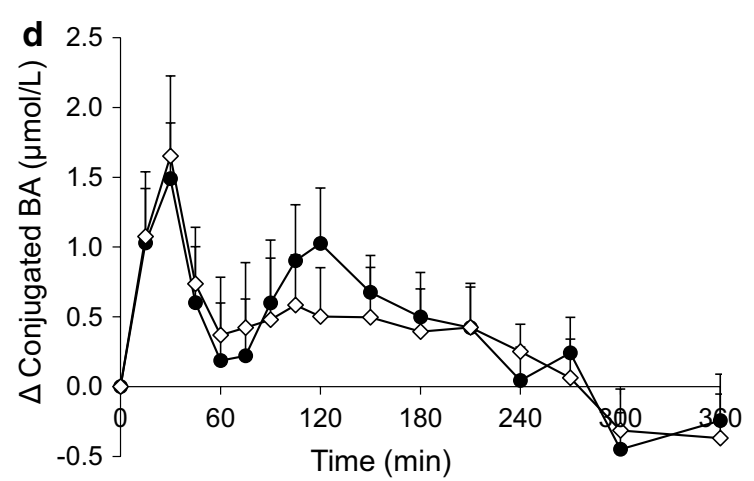

${ }^{13} \mathrm{C}$-enriched kernel bread (open diamond) in healthy men $(n=10)$. There were no significant time $\times$ treatment interactions. $C C K$ cholecystokinin, $B A$ bile acid
Table 3 Correlation coefficients relating the glucose, insulin, GIP, GLP-1, conjugated and total BA concentrations, and $\mathrm{RaE}$ after ingestion of $138 \mathrm{~g}$ ${ }^{13} \mathrm{C}$-enriched $\mathrm{CB}$ and $137 \mathrm{~g}$

${ }^{13} \mathrm{C}$-enriched $\mathrm{KB}$

\begin{tabular}{|c|c|c|c|c|c|c|c|c|c|c|c|c|c|c|}
\hline & \multicolumn{2}{|c|}{ Glucose } & \multicolumn{2}{|c|}{ Insulin } & \multicolumn{2}{|l|}{ GIP } & \multicolumn{2}{|c|}{ GLP-1 } & \multicolumn{2}{|l|}{$\mathrm{RaE}$} & \multicolumn{2}{|c|}{ BA con } & \multicolumn{2}{|c|}{ BA tot } \\
\hline & $\mathrm{CB}$ & $\mathrm{KB}$ & $\mathrm{CB}$ & $\mathrm{KB}$ & $\mathrm{CB}$ & $\mathrm{KB}$ & CB & KB & CB & KB & $\mathrm{CB}$ & KB & CB & KB \\
\hline \multicolumn{15}{|l|}{ Glucose } \\
\hline Insulin & 0.86 & 0.83 & & & & & & & & & & & & \\
\hline GIP & 0.57 & 0.56 & 0.55 & 0.63 & & & & & & & & & & \\
\hline GLP-1 & 0.41 & 0.43 & 0.41 & 0.46 & 0.59 & 0.69 & & & & & & & & \\
\hline $\mathrm{RaE}$ & 0.73 & 0.71 & 0.66 & 0.76 & 0.84 & 0.71 & 0.70 & 0.58 & & & & & & \\
\hline BA con & 0.21 & 0.24 & 0.18 & 0.41 & 0.34 & 0.27 & 0.60 & 0.39 & 0.41 & 0.38 & & & & \\
\hline BA tot & 0.23 & 0.25 & 0.19 & 0.39 & 0.26 & 0.25 & 0.53 & 0.43 & 0.35 & 0.27 & 0.94 & 0.89 & & \\
\hline
\end{tabular}

The within-subject relationship (correlation) between variables was tested by regression analysis according to the method of Bland and Altman [35], $P<0.05$

$B A$ con conjugated bile acids, $B A$ tot total bile acids, $C B$ control bread, $G I P$ glucose-dependent insulinotropic polypeptide, $G L P-1$ glucagon-like peptide-1, $K B$ kernel bread, $R a E$ rate of appearance of exogenous glucose
GLP-1 by luminal contact [40]. Although several mechanisms have been proposed with respect to glucose sensing, in the early postprandial phase GLP-1 secretion seems to mainly involve the SGLT-1 glucose transporter in L cells, similar to GIP secretion from $\mathrm{K}$ cells [41, 42]. In the present study, glucose transport across the intestinal membrane is reflected by the $\mathrm{RaE}$, which correlated well with
GLP-1 concentrations after the CB $(r=0.70, P<0.01)$, but more moderately after the KB $(r=0.58, P<0.01)$. However, the correlations of RaE with GIP (CB: $r=0.84$ and KB: $r=0.71, P<0.01$ ), which are in accordance with our previous studies [31, 34], were stronger. The involvement of additional factors in stimulating GLP-1 release in the present study is thus likely. 
We expected that due to the larger particle size in $\mathrm{KB}$, more starch would reach the more abundant distal L cells, resulting in an increased late postprandial GLP-1 response. This was, for instance, seen in a study with slowly digestible starch, together with a prolonged influx of glucose [31]. However, the GLP-1 response was prolonged after $\mathrm{CB}$, but not after KB consumption, even though intestinal glucose uptake did not differ between our breads.

Moreover, with inhibition of SGLT-1 and in SGLT-1-/mice, a late prolonged increase in GLP-1 after a glucose load was observed [43], besides the decreased GIP and GLP-1 responses in the early postprandial phase [41, 42]. This indicates that the late postprandial GLP-1 response might not require glucose absorption via SGLT-1 [43]. Because L cells are densely distributed in the distal small intestine and colon, it might be that only the presence of still unabsorbed carbohydrates is important in stimulating GLP-1 in the late postprandial phase, for instance via other glucose-sensing mechanisms.

A prolonged postprandial GLP-1 response was also observed when sucrose digestion was delayed by acarbose [44, 45], which was linked to a simultaneous increase in breath hydrogen after 60-120 min, related to fermentation of sucrose. Another explanation for GLP-1 secretion in the late postprandial phase is therefore the involvement of short chain fatty acids (SCFAs), produced during fermentation of unabsorbed carbohydrates or fiber by the intestinal microbiota, and known to stimulate GLP-1 secretion as well [46]. Although fermentation of solid food may be expected in a later phase, in a previous study using ${ }^{13} \mathrm{C}$-labeled barley, ${ }^{13} \mathrm{C}$-labeled SCFAs in plasma were detected within $3 \mathrm{~h}$ after ingestion [23]. Increased SCFA formation after CB may be expected due to the presence of finer wheat bran [47].

In addition to nutrients and SCFAs, BAs are also able to potentiate GLP-1 release via activation of the BA receptor TGR5 [13, 14, 48]. Besides in vitro and animal data, in healthy humans, jejunal infusion with TCA and glucose increased GLP-1 concentrations [49]. In our study, conjugated bile acids in plasma increased, whereas the unconjugated BAs decreased after bread consumption. These observations are in agreement with those of others made after an OGTT [50, 51]. However, to the best of our knowledge, so far the differences in BA responses after various starchy food products have not yet been investigated. After KB consumption, the total BA response tended to be lower compared to $\mathrm{CB}$ (from $t=90 \mathrm{~min}$ ), but differences were not significant and large inter-individual variations were observed. CCK, involved in regulating gall bladder contraction and thus BA release, showed only a slight increase in response to the test meals, which also tended to be somewhat lower for $\mathrm{KB}$ between 90 and 180 min postprandial. However, an apparent difference between $\mathrm{CCK}$ and $\mathrm{BA}$ response patterns was the peak in BA concentration during the first $60 \mathrm{~min}$, which was not detected in the CCK response in the present study.
We found a moderate correlation between GLP-1 and total BAs (CB $r=0.53$, KB $r=0.43$ ) and GLP-1 and conjugated BAs ( $\mathrm{CB} r=0.60, \mathrm{~KB} r=0.39$ ), indicating that there may be a relationship between the BA and GLP-1 response. In agreement, another study found a correlation of GLP-1 with mainly glycine-conjugated BAs and total BAs after ingestion of a mixed meal [52]. The correlation coefficients for $\mathrm{KB}$ were clearly lower compared to $\mathrm{CB}$, and as mentioned earlier, lower values for $\mathrm{KB}$ were also observed when correlating RaE with GIP and GLP-1. Because the interactions are likely to happen in the intestine, it might be that the more preserved kernel structure in $\mathrm{KB}$ resulted in less accurate glucose-sensing or interfered in BA binding by the $\mathrm{K}$ and/or L cells.

It should also be kept in mind that the BAs measured in the systemic circulation do not necessarily directly reflect what happens in the intestine as, for instance, reabsorption of BAs might be influenced by food components. Fiber was found to bind BAs to a certain extent [53], and with respect to bran, especially more finely milled wheat bran was suggested to have higher BA binding capacity [54]. Thus, the finer wheat bran fiber in CB could have bound more BAs, preventing reabsorption and resulting in higher exposure of the $\mathrm{L}$ cells to BAs in the distal small intestine and colon, thereby contributing to the higher late GLP-1 response after CB. In support of this, it was shown in rodents that BA sequestrant administration could increase fecal BAs, stimulate TGR5 on L cells located in the colon, and increase postprandial GLP-1 concentrations [55]. Moreover, rectal infusion of TCA in obese T2DM patients resulted in a pronounced, dose-dependent GLP-1 response [56].

More research is necessary to understand the complex regulation of postprandial GLP-1 stimulation and the possible role of BAs. Therapies that increase BAs (or mimetics) in the distal bowel as a means of increasing endogenous GLP-1 concentrations have been suggested as novel treatments of T2DM and obesity [56]. Several other approaches to increase GLP-1 action are being intensively studied for their potential therapeutic use. Furthermore, because of the beneficial effects in T2DM patients, treatment with GLP-1 analogs was also proposed for people with prediabetes to prevent progression to T2DM [57, 58]. Pharmaceutical intervention might, however, have downsides, and increasing endogenous GLP-1 concentrations by nutritional means would therefore be interesting.

Some potential limitations of this study should be considered. The breads were frozen after baking, to keep them fresh during the whole study period (4-week). Differential effects on digestibility of starch in the control or kernel bread cannot be excluded. Furthermore, we did not measure the protein content of the products. Protein can affect the blood glucose response, by influencing the insulin response independent of carbohydrates. However, 
we expected the protein content to be very similar, as both breads were made from the same wheat type and also had the same starch content.

To conclude, the substitution of $85 \%$ wheat flour by broken kernels in bread did not result in any difference in glucose response and kinetics, but did elicit a pronounced difference in GLP-1 responses. Because of the complex regulation of GLP-1 release, several factors could simultaneously play a role after consumption of food products such as bread. Plasma bile acids showed a pronounced response after the breads, which might play a role in GLP-1 stimulation.

Our findings show that the glycemic response is not the only parameter which can determine health effects of starchy foods. The GLP-1 response is apparently largely independent from glucose kinetics and might be influenced by other characteristics of starchy food products. Therefore, our finding shows that bread processing technology can influence metabolic response beyond glycemia, which offers significant opportunities.

Acknowledgments We thank Theo Boer for GC/MS and GC/C/ IRMS analyses, Marianne Schepers and Gerlof Reckman for laboratory procedures, Tom Preston for providing ${ }^{13} \mathrm{C}$-enriched wheat kernels, Eric Schoen and Carina de Jong for statistical analysis using GenStat and Thérèse Maarschalkerweerd for making microscopic images. This study was funded by Top Institute Food and Nutrition, Wageningen, The Netherlands.

\section{Compliance with ethical standards}

Conflicts of interest All authors declare that there are no conflicts of interest.

Open Access This article is distributed under the terms of the Creative Commons Attribution 4.0 International License (http://creativecommons.org/licenses/by/4.0/), which permits unrestricted use, distribution, and reproduction in any medium, provided you give appropriate credit to the original author(s) and the source, provide a link to the Creative Commons license, and indicate if changes were made.

\section{References}

1. Ludwig DS (2002) The glycemic index: physiological mechanisms relating to obesity, diabetes, and cardiovascular disease. JAMA 287:2414-2423

2. Salmeron J, Ascherio A, Rimm EB, Colditz GA, Spiegelman D, Jenkins DJ, Stampfer MJ, Wing AL, Willett WC (1997) Dietary fiber, glycemic load, and risk of NIDDM in men. Diabetes Care 20:545-550

3. Willett W, Manson J, Liu S (2002) Glycemic index, glycemic load, and risk of type 2 diabetes. Am J Clin Nutr 76:274S-280S

4. Thomas D, Elliott EJ, Baur L (2007) Low glycaemic index or low glycaemic load diets for overweight and obesity. Cochrane Database Syst Rev (3):CD005105

5. Thomas D, Elliott EJ (2009) Low glycaemic index, or low glycaemic load, diets for diabetes mellitus. Cochrane Database Syst Rev (1):CD006296
6. Sluijs I, Beulens JW, van der Schouw YT, van der A DL, Buckland G, Kuijsten A, Schulze MB, Amiano P, Ardanaz E, Balkau B, Boeing H, Gavrila D, Grote VA, Key TJ, Li K, Nilsson P, Overvad K, Palli D, Panico S, Quiros JR, Rolandsson O, Roswall N, Sacerdote C, Sanchez MJ, Sieri S, Slimani N, Spijkerman AM, Tjonneland A, Tumino R, Sharp SJ, Langenberg C, Feskens EJ, Forouhi NG, Riboli E, Wareham NJ, InterAct consortium (2013) Dietary glycemic index, glycemic load, and digestible carbohydrate intake are not associated with risk of type 2 diabetes in eight European countries. J Nutr 143:93-99

7. Hodge AM, English DR, O'Dea K, Giles GG (2004) Glycemic index and dietary fiber and the risk of type 2 diabetes. Diabetes Care 27:2701-2706

8. Yip RGC, Wolfe MM (2000) GIP biology and fat metabolism. Life Sci 66:91-103

9. Nauck MA, Niedereichholz U, Ettler R, Holst JJ, Ørskov C, Ritzel R, Schmiegel WH (1997) Glucagon-like peptide 1 inhibition of gastric emptying outweighs its insulinotropic effects in healthy humans. Am J Physiol 273:E981-E988

10. Nauck MA, Kleine N, Ørskov C, Holst JJ, Willms B, Creutzfeldt W (1993) Normalization of fasting hyperglycaemia by exogenous glucagon-like peptide 1 (7-36 amide) in type 2 (non-insulin-dependent) diabetic patients. Diabetologia 36:741-744

11. Flint A, Raben A, Astrup A, Holst JJ (1998) Glucagon-like peptide 1 promotes satiety and suppresses energy intake in humans. $\mathrm{J}$ Clin Invest 101:515-520

12. Drucker DJ (2003) Glucagon-like peptides: regulators of cell proliferation, differentiation, and apoptosis. Mol Endocrinol 17:161-171

13. Thomas C, Gioiello A, Noriega L, Strehle A, Oury J, Rizzo G, Macchiarulo A, Yamamoto H, Mataki C, Pruzanski M, Pellicciari R, Auwerx J, Schoonjans K (2009) TGR5-mediated bile acid sensing controls glucose homeostasis. Cell Metab 10:167-177

14. Rafferty EP, Wylie AR, Hand KH, Elliott CE, Grieve DJ, Green BD (2011) Investigating the effects of physiological bile acids on GLP-1 secretion and glucose tolerance in normal and GLP-1R-/mice. Biol Chem 392:539-546

15. Shaham O, Wei R, Wang TJ, Ricciardi C, Lewis GD, Vasan RS, Carr SA, Thadhani R, Gerszten RE, Mootha VK (2008) Metabolic profiling of the human response to a glucose challenge reveals distinct axes of insulin sensitivity. Mol Syst Biol $4: 214$

16. Zhao X, Peter A, Fritsche J, Elcnerova M, Fritsche A, Haring HU, Schleicher ED, Xu G, Lehmann R (2009) Changes of the plasma metabolome during an oral glucose tolerance test: is there more than glucose to look at? Am J Physiol Endocrinol Metab 296:E384-E393

17. Holt SHA, Brand Miller JC (1994) Particle size, satiety and the glycaemic response. Eur J Clin Nutr 48:496-502

18. Jenkins DJA, Wesson V, Wolever TMS, Jenkins AL, Kalmusky J, Guidici S, Csima A, Josse RG, Wong GS (1988) Wholemeal versus wholegrain breads: proportion of whole or cracked grain and the glycaemic response. Br Med J 297:958-960

19. Eelderink C, Noort MW, Sozer N, Koehorst M, Holst JJ, Deacon CF, Rehfeld JF, Poutanen K, Vonk RJ, Oudhuis L, Priebe MG (2015) The structure of wheat bread influences the postprandial metabolic response in healthy men. Food Funct 6:3236-3248

20. Tissot S, Normand S, Guilluy R, Pachiaudi C, Beylot M, Laville M, Cohen R, Mornex R, Riou JP (1990) Use of a new gas chromatograph isotope ratio mass spectrometer to trace exogenous ${ }^{13} \mathrm{C}$ labelled glucose at a very low level of enrichment in man. Diabetologia 33:449-456

21. Priebe MG, Wang H, Weening D, Schepers M, Preston T, Vonk RJ (2010) Factors related to colonic fermentation of nondigestible carbohydrates of a previous evening meal increase tissue 
glucose uptake and moderate glucose-associated inflammation. Am J Clin Nutr 91:90-97

22. Englyst KN, Englyst HN, Hudson GJ, Cole TJ, Cummings JH (1999) Rapidly available glucose in foods: an in vitro measurement that reflects the glycemic response. Am J Clin Nutr 69:448-454

23. Verbeke K, Ferchaud-Roucher V, Preston T, Small AC, Henckaerts L, Krempf M, Wang H, Vonk RJ, Priebe MG (2010) Influence of the type of indigestible carbohydrate on plasma and urine short-chain fatty acid profiles in healthy human volunteers. Eur J Clin Nutr 64:678-684

24. AACCI (2000) Method 10-05.01. Guidelines for measurement of volume by rapeseed displacement. In: Approved methods of analysis, 11th edition edn. AACC International, St. Paul

25. Flint A, Raben A, Blundell JE, Astrup A (2000) Reproducibility, power and validity of visual analogue scales in assessment of appetite sensations in single test meal studies. Int $\mathbf{J}$ Obes 24:38-48

26. Ørskov C, Jeppesen J, Madsbad S, Holst JJ (1991) Proglucagon products in plasma of noninsulin-dependent diabetics and nondiabetic controls in the fasting state and after oral glucose and intravenous arginine. J Clin Invest 87:415-423

27. Lindgren O, Carr RD, Deacon CF, Holst JJ, Pacini G, Mari A, Ahren B (2011) Incretin hormone and insulin responses to oral versus intravenous lipid administration in humans. J Clin Endocrinol Metab 96:2519-2524

28. Ørskov C, Rabenhøj L, Wettergren A, Kofod H, Holst JJ (1994) Tissue and plasma concentrations of amidated and glycine-extended glucagon-like peptide I in humans. Diabetes 43:535-539

29. Rehfeld JF (1998) Accurate measurement of cholecystokinin in plasma. Clin Chem 44:991-1001

30. Vonk RJ, Stellaard F, Priebe MG, Koetse HA, Hagedoorn RE, De BS, Elzinga H, Lenoir-Wijnkoop I, Antoine JM (2001) The ${ }^{13} \mathrm{C} /{ }^{2} \mathrm{H}$-glucose test for determination of small intestinal lactase activity. Eur J Clin Invest 31:226-233

31. Wachters-Hagedoorn RE, Priebe MG, Heimweg JA, Heiner AM, Englyst KN, Holst JJ, Stellaard F, Vonk RJ (2006) The rate of intestinal glucose absorption is correlated with plasma glucosedependent insulinotropic polypeptide concentrations in healthy men. J Nutr 136:1511-1516

32. Vonk RJ, Hagedoorn RE, De Graaff R, Elzinga H, Tabak S, Yang YX, Stellaard F (2000) Digestion of so-called resistant starch sources in the human small intestine. Am J Clin Nutr 72:432-438

33. Eelderink C, Moerdijk-Poortvliet TC, Wang H, Schepers M, Preston T, Boer T, Vonk RJ, Schierbeek H, Priebe MG (2012) The glycemic response does not reflect the in vivo starch digestibility of fiber-rich wheat products in healthy men. J Nutr 142(2):258-263

34. Eelderink C, Schepers M, Preston T, Vonk RJ, Oudhuis L, Priebe MG (2012) Slowly and rapidly digestible starchy foods can elicit a similar glycemic response because of differential tissue glucose uptake in healthy men. Am J Clin Nutr 96:1017-1024

35. Bland JM, Altman DG (1995) Calculating correlation coefficients with repeated observations: part 1-correlation within subjects. BMJ 310:446

36. Fardet A, Leenhardt F, Lioger D, Scalbert A, Remesy C (2006) Parameters controlling the glycaemic response to breads. Nutr Res Rev 19:18-25

37. Holm J, Bjorck I (1992) Bioavailability of starch in various wheat-based bread products: evaluation of metabolic responses in healthy subjects and rate and extent of in vitro starch digestion. Am J Clin Nutr 55:420-429

38. Liljeberg H, Granfeldt Y, Bjorck I (1992) Metabolic responses to starch in bread containing intact kernels versus milled flour. Eur J Clin Nutr 46:561-575
39. Burton P, Lightowler HJ (2006) Influence of bread volume on glycaemic response and satiety. Br J Nutr 96:877-882

40. Eissele R, Goke R, Willemer S, Harthus HP, Vermeer H, Arnold R, Goke B (1992) Glucagon-like peptide-1 cells in the gastrointestinal tract and pancreas of rat, pig and man. Eur J Clin Invest 22:283-291

41. Moriya R, Shirakura T, Ito J, Mashiko S, Seo T (2009) Activation of sodium-glucose cotransporter 1 ameliorates hyperglycemia by mediating incretin secretion in mice. Am J Physiol Endocrinol Metab 297:E1358-E1365

42. Gorboulev V, Schurmann A, Vallon V, Kipp H, Jaschke A, Klessen D, Friedrich A, Scherneck S, Rieg T, Cunard R, VeyhlWichmann M, Srinivasan A, Balen D, Breljak D, Rexhepaj R, Parker HE, Gribble FM, Reimann F, Lang F, Wiese S, Sabolic I, Sendtner M, Koepsell H (2012) Na(+)-D-glucose cotransporter SGLT1 is pivotal for intestinal glucose absorption and glucosedependent incretin secretion. Diabetes 61:187-196

43. Powell DR, Smith M, Greer J, Harris A, Zhao S, DaCosta C, Mseeh F, Shadoan MK, Sands A, Zambrowicz B, Ding ZM (2013) LX4211 increases serum glucagon-like peptide 1 and peptide YY levels by reducing sodium/glucose cotransporter 1 (SGLT1)-mediated absorption of intestinal glucose. J Pharmacol Exp Ther 345:250-259

44. Qualmann C, Nauck MA, Holst JJ, Ørskov C, Creutzfeldt W (1995) Glucagon-like peptide 1 (7-36 amide) secretion in response to luminal sucrose from the upper and lower gut. A study using $\alpha$-glucosidase inhibition (acarbose). Scand J Gastroenterol 30:892-896

45. Seifarth C, Bergmann J, Holst JJ, Ritzel R, Schmiegel W, Nauck MA (1998) Prolonged and enhanced secretion of glucagon-like peptide 1 (7-36 amide) after oral sucrose due to alpha-glucosidase inhibition (acarbose) in Type 2 diabetic patients. Diabetes Med 15:485-491

46. Tolhurst G, Heffron H, Lam YS, Parker HE, Habib AM, Diakogiannaki E, Cameron J, Grosse J, Reimann F, Gribble FM (2012) Short-chain fatty acids stimulate glucagon-like peptide-1 secretion via the G-protein-coupled receptor FFAR2. Diabetes 61:364-371

47. Jenkins DJA, Kendall CWC, Vuksan V, Augustin LSA, Li Y-, Lee B, Mehling CC, Parker T, Faulkner D, Seyler H, Vidgen E, Fulgoni V III (1999) The effect of wheat bran particle size on laxation and colonic fermentation. J Am Coll Nutr 18:339-345

48. Katsuma S, Hirasawa A, Tsujimoto G (2005) Bile acids promote glucagon-like peptide-1 secretion through TGR5 in a murine enteroendocrine cell line STC-1. Biochem Biophys Res Commun 329:386-390

49. Wu T, Bound MJ, Standfield SD, Jones KL, Horowitz M, Rayner CK (2013) Effects of taurocholic acid on glycemic, glucagon-like peptide-1, and insulin responses to small intestinal glucose infusion in healthy humans. J Clin Endocrinol Metab 98:E718-E722

50. Matysik S, Martin J, Bala M, Scherer M, Schaffler A, Schmitz G (2011) Bile acid signaling after an oral glucose tolerance test. Chem Phys Lipids 164:525-529

51. Ho JE, Larson MG, Vasan RS, Ghorbani A, Cheng S, Rhee EP, Florez JC, Clish CB, Gerszten RE, Wang TJ (2013) Metabolite profiles during oral glucose challenge. Diabetes 62:2689-2698

52. Roberts RE, Glicksman C, Alaghband-Zadeh J, Sherwood RA, Akuji N, le Roux CW (2011) The relationship between postprandial bile acid concentration, GLP-1, PYY and ghrelin. Clin Endocrinol (Oxf) 74:67-72

53. Story JA, Kritchevsky D (1976) Comparison of the binding of various bile acids and bile salts in vitro by several types of fiber. J Nutr 106:1292-1294

54. Kahlon T, de Berrios JJ, Smith G, Pan J (2006) In vitro bile acid binding capacity of milled wheat bran and milled extruded wheat bran at five specific mechanical energy levels. Cereal Chem $83: 434-438$ 
55. Harach T, Pols TW, Nomura M, Maida A, Watanabe M, Auwerx J, Schoonjans K (2012) TGR5 potentiates GLP-1 secretion in response to anionic exchange resins. Sci Rep 2:430

56. Adrian TE, Gariballa S, Parekh KA, Thomas SA, Saadi H, Al Kaabi J, Nagelkerke N, Gedulin B, Young AA (2012) Rectal taurocholate increases $\mathrm{L}$ cell and insulin secretion, and decreases blood glucose and food intake in obese type 2 diabetic volunteers. Diabetologia 55:2343-2347
57. DeFronzo RA, Abdul-Ghani M (2011) Type 2 diabetes can be prevented with early pharmacological intervention. Diabetes Care 34:S202-S209

58. Holst JJ, Deacon CF (2013) Is there a place for incretin therapies in obesity and prediabetes? Trends Endocrinol Metab 24:145-152 